\title{
УКРАЇНОЗНАВСТВО В ХАРКІВСЬКОМУ УНІВЕРСИТЕТІ В ПРОЦЕСІ СТАНОВЛЕННЯ УКРАЇНСЬКОЇ МОДЕРНОЇ НАЦІЇ ХІХ - ПОЧАТКУ ХХ СТ.
}

\section{С. I. Свімленко}

Світленко C. I. Українознавство в Харківському університеті в процесі становлення української модерної нації XIX - початку XX ст. Розглянуто процес поступу українознавчих студій у Харківському університеті в XIX - на початку XX ст. Показано, що вже наприкінці 1820-х - упродовж 1840-х рр. ряд професорів, викладачів та студентів працювали у галузях історії, фольклористики, етнографії, літератури, видавничої справи, вивчаючи поетичну та пісенну спадщину українського народу. Ідея українського національно-культурного поступу, основи якої закладалися в соціальну практику харківської університетської спільноти на культурницькому етапі українського націотворення, набули більшої зрілості на наступному культурно-політичному етапі національно-визвольних змагань і значно активніше виявлялися впродовж 1860-1880-х рр., коли вчені-україністи перейшли на позиції методології позитивізму. На рубежі XIX-XX ст., коли поступово утверджувалася політична стадія українського націотворення, представники патріотично налаштованої частини професорсько-викладацького складу та студентства Харківського університету продовжили і поглибили розвиток різних галузей українознавства, актуалізуючи відповідну проблематику за суспільно-політичних умов російського імперського режиму. Діяльність української інтелектуальної спільноти мала важливе значення у справі відстоювання права українського народу на власну мову, освіту, науку та культуру, сприяла поступу української національної свідомості та ідентичності. Українознавчі студії харківських вчених часто здійснювались водночас з їхніми науковими дослідженнями в різних галузях славістики.

Ключові слова: українознавство, українське націотворення, українська інтелектуальна спільнота Харківського університету, українська національна свідомість.

Светленко С. И. Украиноведение в Харьковском университете в процессе становления украинской современной нации XIX - начала XX в. Рассмотрен процесс развития украиноведческих исследований в Харьковском университете в XIX - начале XX в. Показано, что уже в конце 1820-1840-х гг. ряд профессоров, преподавателей и студентов работали в области истории, фольклористики, этнографии, литературы, издательского дела, изучая поэтическое и песенное наследие украинского народа. Идея украинского национально-культурного развития, основы которой закладывались в социальную практику харьковского университетского сообщества на культурническом этапе создания украинской нации, приобрели большую зрелость на следующем культурно-политическом этапе национально-освободительной борьбы и значительно активнее проявлялись в течение 1860-1880-х гг., когда ученые-украинисты перешли на позиции методологии позитивизма. На рубеже XIX-XX вв., когда постепенно утверждалась политическая стадия создания украинской нации, представители патриотически настроенной части профессорско-преподавательского состава и студенчества Харьковского университета продолжили и углубили развитие различных отраслей украиноведения, актуализируя соответствующую проблематику в общественно-политических условиях российского имперского режима. Деятельность украинского интеллектуального сообщества имела важное значение в деле отстаивании права украинского народа на собственный язык, образование, науку и культуру, способствовала развитию украинского национального сознания и идентичности. Украиноведческие студии харьковских ученых часто осуществлялись одновременно с их научными исследованиями в различных областях славистики.

Ключевые слова: украиноведение, пробуждение украинской нации, украинское интеллектуальное сообщество Харьковского университета, украинское национальное сознание.

Svitlenko S. I. Ukrainian Studies at Kharkov University in the Process of Becoming a Ukrainian Modern Nation from the $19^{\text {th }}$ till Early $\mathbf{2 0}^{\text {th }}$ Century. The process of development of Ukrainian studies at Kharkiv University in the $19^{\text {th }}$ - early $20^{\text {th }}$ century was considered. It is shown that already in the late $1820 \mathrm{~s}$ - during the 1840s a number of professors, teachers and students worked in the fields of history, folklore, ethnography, literature, publishing, studying poetry and song heritage of the Ukrainian people. The idea of Ukrainian national-cultural progress, the foundations of which were laid in the social practice of Kharkov University community on the cultural stage of the Ukrainian nation, enjoy a greater maturity on the following cultural-political stage of the national-liberation competitions and much more were revealed 
during the 1860-1880s, when scientists-Ukrainists moved to the position of methodology of positivism. At the turn of the $19^{\text {th }}$ and $20^{\text {th }}$ centuries, when the political stage of Ukrainian nationalization gradually became firmly established, representatives of the patriotic part of the faculty and students of the Kharkov University continued and deepened the development of various branches of Ukrainian studies, actualizing the relevant issues in the socio-political conditions of the Russian imperial regime. The activities of the Ukrainian intellectual community has been important in defending the Ukrainian people's right to their own language, education, science and culture contributed to the progress of Ukrainian national consciousness and identity. Kharkiv scholars' Ukrainian studies studios were often carried out at the same time as their scientific research in various fields of Slavic studies.

Keywords: Ukrainian studies, awakening of the Ukrainian nation, the Ukrainian intellectual community of Kharkov University, Ukrainian national consciousness.

Постановка проблеми. Термін «становлення української модерної нації» стосовно XIX - початку XX ст. може бути використаний з огляду на те, що в зазначений період відбувався процес формування й розвитку українського модерного націотворення. Останнє виникло не на порожньому місці, а набувало нових, властивих йому якісних рис, використовуючи традиції українського раннього модерну, котрий вже втратив свій історичний потенціал із занепадом на Лівобережжі Гетьманської України, наступом на права правобережного українського козацтва та з ліквідацією Запорозької Січі. Тим часом на землях Наддніпрянщини (в широкому сенсі цього історико-географічного поняття) розгорнувся процес інкорпорації, тобто приєднання до складу Російської імперії. Все, що не вкладалося в російську імперську модель, в якій перепліталися російські династичні, монархічні й національні начала, мало припинити своє самодостатнє функціонування або пристосовуватися до нових державно-політичних реалій.

Важливо усвідомлювати, що український національний модерн набував поступу не тільки на основі трансформованої в нових умовах традиції ранньомодерної України, а значною мірою на власній інтелектуальній основі. В процесі творення української модерної нації особлива роль належала університетам Наддніпрянщини, хоча вони засновувалися з іншою метою - зміцнити позиції російського самодержавства в цій частині імперії. Втім, ці вищі навчальні заклади відіграли свою роль саме у формуванні української нації в процесі набуття нею модерного змісту, хоча, звичайно, цей процес не можна спрощувати і розглядати як однолінійний по висхідній. Адже імперський режим розглядав підросійську Україну як провінційну й не самодостатню частину «єдиного і неподільного» російського державно-політичного, соціально-економічного, духовно-культурного та освітньо-наукового простору. I лише з цього погляду царська влада й дозволяла українознавство («південнорусознавство») як певну сукупність знань про українські («малоросійські», «новоросійські» тощо) землі й людність.

Втім, ряд українських учених, займаючись вивченням рідної землі, раз по раз виходили за межі імперського інтелектуального проекту, а інколи конструювали у своїй свідомості власний український. Звичайно, світоглядний шлях інтелектуалів від імперського світобачення через феномен подвійної лояльності з ії «малоросійством» та «етнографічним українофільством» до відчуття себе українцями був вельми непростим. 3 цього погляду вивчення українознавчих студій в Харківському університеті представляє значний дослідницький інтерес, оскільки проливає додаткове світло на складний процес зародження i розвитку української національної свідомості та ідентичності.

Аналіз наукових досліджень. Деякі важливі аспекти поступу університетського українознавства в Харкові вже розглядалися в сучасній історіографії. Достатньо згадати ювілейні видання, присвячені зазначеному університету. Так, у колективній монографії «Харківський університет і українська культура (210-річчя від часу заснування ХНУ імені В. Н. Каразіна)» (Х., 2015) представляє інтерес розділ 1 «Харківський університет і українське національне відродження в першій половині XIX століття» та розділ 2 «Внесок Харківського університету у розвиток української культури другої половини XIX - початку ХХ століть» ${ }^{1}$.

Помітним кроком уперед у розробці зазначеної теми стали й деякі сучасні одноосібні монографії, присвячені видатним професорам Харьківського університету, котрі зробили вагомий внесок у поступ українознавчих студій. Це, зокрема, дослідження О. Мандебури про М. Ф. Сумцова, де розкрито вклад ученого у становлення вітчизняного україно- 
знавства ${ }^{2}$; праця В. Ю. Франчук про О. О. Потебню, в якій чільне місце посіли сюжети, пов'язані з громадською і науковою діяльністю визначного вченого-патріота в галузі українознавства ${ }^{3}$; монографія В. І. Юрчука про Д. І. Багалія, в якій висвітлено формування українознавчих поглядів визначного науковця, відмітні риси і особливості та значення його українознавчої творчості тощо 4 . В цілому можна констатувати, що на сучасному етапі вже чимало зроблено для пізнання розвитку українознавства в Харківському університеті в XIX - на початку XX ст. Втім, ця важлива тема в контексті українського модерного націотворення заслуговує на поглиблене вивчення, оскільки має суттєве значення для глибоке осягнення особливостей та тенденцій цього складного процесу на регіональному рівні.

Метою даного дослідження $\epsilon$ вивчення особливостей поступу українознавства в Харківському університеті в процесі становлення української модерної нації XIX - початку XX ст.

Виклад основного матеріалу цілком логічно розпочати із зародження і розвитку україністики у Харківському університеті, який постав на Слобожанщині в 1805 р. Вже незабаром тут закладаються передумови поступу українознавчих студій. Як відмічала О. Я. Єфименко, вже через десятиліття після відкриття Харківського університету в місті зроблено спроби заснування ряду періодичних видань, таких як «Харьковский Демокрит» (1816), «Украинский Вестник» (1816-1819), «Украинский Журнал» (1824-1825)5.

Свого часу Д. І. Багалій і Д. П. Міллер вважали, що малоруський літературний рух виріс не внаслідок якого-небудь зовнішнього впливу, наприклад польського, «а як природнє бажання виражати українське народне життя українською ж народною мовою». У цьому контексті називалися імена, насамперед, П. П. Гулака-Артемовського та Г. Ф. КвіткиОснов'яненка, які творили в галузі українознавства завдяки своїй глибокій внутрішній потребі.

П. П. Гулак-Артемовський пройшов непростий життєвий шлях від вільно- слухача Харківського університету в 1816/17 н.р. до ректора цього навчального закладу в $1841-$ 1849 рр. Але в історії він закарбувався не стільки як яскравий зразок адміністратора-бюрократа миколаївської епохи, а як великий природний поетичний талант. Добре знайомий 3 дитинства 3 українським народом, його сільським побутом, звичаями та особливостями національного духу, П. П. Гулак-Артемовський на підсвідомому рівні сприйняв всю красу української народної мови, досконало володів і став користуватися нею у своїй поетичній творчості. Обробка сюжетів його творів, до речі, запозичених із польської літератури, і за формою, і за змістом була глибоко українською, наскрізь просякнутою народною думкою, духом та образами. Така поезія, за свідченням сучасника, пробуджувала в суспільстві «інтерес і любов до південно-руської народності» ${ }^{6}$. П. П. Гулак-Артемовський зробив помітний особистий внесок у поступ українознавства: писав популярні українські байки, запровадив в українській літературі жанр української балади, працював у ліричному жанрі народнопісенного характеру․

Не менш колоритною постаттю був Г. Ф. Квітка-Основ'яненко - яскравий представник української прози. Досконало володіючи українським словом, люблячи все українське - національну їжу, одяг тощо, письменник частину своїх творів написав рідною мовою, талановито оповідаючи про простолюдне українське сільське життя. В 1833 р. у своїй статті Г. Ф. Квітка-Основ'яненко зробив спробу теоретичного обгрунтування використання народної мови в літературній практиці. «Малоросійські повісті», видані у двох томах у 1834 р., принесли Г. Ф. Квітці-Основ'яненку справжнє літературне визнання й успіх. Адже його називали «батьком» української літератури. Будинок знаного письменника відвідували І. І. Срезневський, А. Л. Метлинський та вся молодь їхнього кола. Виїжджаючи із Харкова, вони продовжували спілкування зі своїм кумиром епістолярнов .

Розвиваючись спочатку на українській етнокультурній основі, часто 3 морально-етичних та естетичних міркувань, українознавчі студії набули поступу в епоху, коли в європейській думці відбувався перехід від просвітницької до романтичної ідеології. Звичайно, свою роль у процесі самоусвідомлення українських культурників відігравали й твори французьких просвітителів, а більшою мірою праці представників німецького романтизму та німецької класичної філософії І. Канта, Й. І. Фіхте та Ф. В. Й. Шеллінга, які в річищі романтичного світогляду акцентували на проявах особливого, національного. Їхні ідеї, поширені послідовником Й. Г. Фіхте професором Й. Б. Шадом та прихильником І. Канта 
професором Л. Г. Якобом у стінах Харківського університету в 1800-1810-х рр., знайшли своїх симпатиків і послідовників ${ }^{9}$.

Наприкінці 1820-1840-х рр. ряд професорів, викладачів і студентів Харківського університету, зокрема I. I. Срезневський, П. П. Гулак-Артемовський, Л. І. Боровиковський, О. С. та Ф. С. Євецькі, О. О. Корсун, М. І. Костомаров, А. Л. Метлинський, М. М. Петренко, І. В. Розковшенко, О. П. Рославський-Петровський, О. Г. Шпигоцький, утворили ядро школи харківських романтиків - провідного осередку українознавчих студій. Ідейним натхненником гуртка став I. I. Срезневський, який разом з I. В. Росковшенком видав «Український альманах» (1831), де було розміщено зразки української усної народної творчості, вірші, балади, наукові та літературно-критичні статті. У 1833-1838 pр. він опублікував в університетській друкарні шість випусків фольклорно-історичного збірника «Запорожская старина», що, кажучи словами М. С. Грушевського, справила «свого часу сильне вражінне на суспільство». У науковій розвідці «Взгляд на пам'ятники украинской народной словесности» (1834) I. I. Срезневський виступив на захист прав української мови, розглядаючи її як окрему й самодостатню.

У 1837 р., ставши професором Харківського університету, I. I. Срезневський, зосередившись на вивченні мов і культур західних та південних слов'ян, став засновником загальноросійської школи славістів. Уже відомий вчений-славіст, він видав «Украинский сборник» у двох книгах $(1838,1841)$. У першій книзі видання, опублікованій у Харкові, було вперше надруковано вельми популярні вистави засновника нової української літератури I. П. Котляревського «Москаль-чарівник» $\mathrm{i}$ «Наталка Полтавка». Таким чином, у творчості I. I. Срезневського українознавство перепліталося зі слов'янознавством, 3 приводу чого М. С. Грушевський писав: «Українські письменники подають руку слов'янському відродженню і романтичним інтересам до народності» ${ }^{10}$.

Інтерес I. I. Срезневського до слов'янознавства не був випадковим. Адже, як відмічала О. Я. Єфименко, в Харків, поряд і з французьким вільнодумством просвітителів, рано проникли ідеї слов'янської взаємності та єдності, пов'язані з ідеєю відродження окремих слов'янських народів. На думку, Д. І. Чижевського, свою роль відігравала модерна польська література, яка розповсюджувалася поряд із російською, знаходячи в Харкові свого читача. Відомо також, що ще засновник Харківського університету В. Н. Каразін свого часу представляв уряду Олександра I проект всеслов'янської держави ${ }^{11}$.

Енергійна й обдарована особистість I. I. Срезневського згуртувала навколо себе стійке коло прихильників, які під його впливом з симпатією ставилися до українського й народного в культурі, науці та суспільному житті. У поетичній, фольклорно-етнографічній та перекладацькій царинах збагатив українознавство один із найближчих сподвижників Ізмаїла Івановича, випускник відділення моральних і політичних наук Харківського університету (1835), а згодом професор російської словесності цього ж навчального закладу (1843-1849, 1854-1858) А. Л. Метлинський. Д. І. Багалій та Д. П. Міллер називали його «душею» харківського гуртка романтиків, а О. Я. Єфименко відмічала його надзвичайну енергію, за якою він переважав навіть I. І. Срезневського.

А. Л. Метлинський друкував свої поезії в харківських літературних альманахах «Сніп» (1841), «Молодик» (1843-1844), опублікував збірку поезій «Думи і пісні та ще дещо» (1839), «Южный русский сборник» у 5 книгах (1848), «Байки й прибаютки Левка Боровиковського» (1852), фольклорну збірку «Народные южно-русские песни» (1854). Пристрасний збирач українських пісень, він надавав чудовий приклад евристичної діяльності харківській студентській молоді. А. Л. Метлинський, як відмічав М. Ф. Сумцов, мав серед студентства «велике коло впливу». Як поет, він розвивав сонет і баладу, перекладав доробок польських, сербських, чеських і словацьких поетів ${ }^{12}$.

До школи харківських романтиків належав М. І. Костомаров, який зацікавився спадщиною українського народу під впливом ідей німецьких романтиків та читання праць видатних репрезентантів українського романтизму. Важливе значення мало і його університетське оточення інтелектуалів-романтиків, до якого входили професори А. Л. Метлинський та О. П. Рославський-Петровський, ад’юнкт-професор I. I. Срезневський. Українознавство так зацікавило М. І. Костомарова, що він став особисто вивчати український народ, здійснюючи етнографічні екскурсії із Харкова по навколишніх селах, а незабаром - на Полтавщині. 
У 1838 р. М. І. Костомаров прийняв рішення писати твори українською мовою. Першими кроками на цьому шляху стала опублікована в Харкові драма «Сава Чалий» (1838), україномовні вірші, об’єднані назвою «Українські балади» (1839), збірка з 30 українських віршів під назвою «Ветка» (1841), трагедія «Переяславська ніч», вміщена у збірника О. О. Корсуна «Сніп» (1841) та ін. Виявом стійкого інтересу молодого вченого до українознавчої тематики стала його перша магістерська дисертація «О причинах и характере унии в Западной России», а після заборони іiї захисту і спалення - друга, успішно захищена, - «Про історичне значення руської народної поезії» ${ }^{13}$.

Розвиток українознавчих студій відбувався в непростих політико-ідеологічних умовах імперського режиму з його цензурними обмеженнями того, що не вкладалося в теорію «офіційної народності». Прикметно, що й тема другої дисертації М. І. Костомарова не зустріла схвалення деяких впливових осіб в університеті, наприклад професора філософії М. М. Протопопов, котрий вважав принизливим для здобувача наукового ступеня вивчати «мужицькі пісні». Проти теми виступив також ректор, професор російської історії і водночас талановитий український літератор П. П. Гулак-Артемовський ${ }^{14}$.

Ще Д. І. Дорошенко відмічав, що наприкінці 1830-х рр. М. І. Костомаров та А. Л. Метлинський друкували у Харкові українські переклади з Краледворського й Зеленогорського рукописів, з народних чеських, сербських і польських пісень. Тоді ж із Харкова зав'язалися безпосередні контакти з Прагою як осередком слов'янського руху ${ }^{15}$. Отже, у М. I. Костомарова та А. Л. Метлинського, як і у I. I. Срезневського, спостерігалося переплетіння інтересу до українознавства і слов'янознавства.

До школи харківських поетів-романтиків належав Л. І. Боровиковський, який ще під час навчання в Харківському університеті (1826-1830) збирав український фольклор, а згодом опублікував фольклорні твори в альманасі «Ластівка» (1841) та у збірнику «Народные южно-русские песни» (1854). Як поет-новатор, він розвивав такі жанри, як літературна пісня, балада, елегія, оспівував історичне минуле України, уславив своє ім'я книжкою «Байки й прибаютки Левка Боровиковського» ${ }^{16}$.

До кола харківських романтиків входив О. О. Корсун, який закінчив юридичний факультет Харківського університету (1842). Ще під час навчання він виявив велике зацікавлення українським фольклором, видав у Харкові збірку «Украинские повір'я» (1839) та альманах «Сніп» (1841). 3-під пера О. О. Корсуна вийшли не тільки українські поезії, а й переклади 3 російської, чеської та польської мов на українську і з української на російську ${ }^{17}$.

Свій внесок у поступ українознавства зробив випускник Харківського університету 1841 р., харківський поет-романтик М. М. Петренко, котрий друкувався в українських альманахах «Молодик» $\mathrm{i}$ «Сніп». Вірші українського поета «Дивлюсь я на небо» та «Туди мої очі» стали народними піснями ${ }^{18}$.

У рамках харківської романтичної школи розпочинав свій творчий шлях ще один випускник історико-філологічного відділення філософського факультету Харківського університету (1848) Я. І. Щоголєв (Щоголів). У роки навчання в університеті він сформувався як український поет, який опублікував ряд своїх поезій у другому випуску альманаху «Молодык» І. Є. Бецького ${ }^{19}$.

Звичайно, українознавча діяльність харківських романтиків-культурників не $є$ свідченням вже наявної у них української національної свідомості. Скоріше можна вести мову про формування подвійної лояльності та ідентичності, які вкладаються в поняття «малоросійство». Втім, збирання і творення ними української культурної спадщини було чинником виникнення у них та їхніх читачів стійкого інтересу до української історії, етнографії, фольклору, культури, що стало підготовчим етапом на шляху до українства.

Нова динаміка у поступі українознавства в Харківському університеті спостерігалася в пореформені десятиліття, що співпали з часом поширення культурно-політичного етапу українського націотворення. Організаційною формою українського руху пореформеного Харкова стала українська громада - напівлегальний гурток, котрий об'єднував ліберальнодемократичну і національно спрямовану інтелігенцію, студентську та учнівську молодь.

Х. Д. Алчевська у своїх спогадах згадувала про Харківську українську громаду 1862 р., котра об'єднувала 80 студентів та семінаристів. У складі гуртка було представлено і немало відомих людей. Це О. К. Алчевський, В. С. Мова, І. С. Нордега та ін. На зборах громадян звучали українські пісні, мова, декларувалися прагнення «зблизитися з народом». 
Громадяни укладали «метелики» - невеличкі брошури літературного та наукового змісту для народу, а також українсько-російський словник, україномовні підручники, проект утворення Товариства любителів української словесності ${ }^{20}$.

Але таке українське культурництво харківських студентів викликало стурбованість чиновників царського режиму. Так, начальник поліції Канівського повіту рапортував Київському, Подільському та Волинському генерал-губернатору 12 травня 1861 р., що Київський i Харківський університети служать головними провідниками й поширювачами ідей «про можливість відновлення Малоросії» ${ }^{21}$.

Студентами Харківського університету, які належали до складу місцевої української громади, зацікавилося III відділення Власної й. і. в. канцелярії, що склало список «малоросійського гуртка» 315 прізвищ. Це, зокрема, Навродцький-Опашанський, Нордега, Дейнега, Бєліков, Гаврилко, Кібалдич, Палкін, Гаврилко, Кремянський, Литевський, Сокович, Нечипуренко, Костенко, Задерака, Завадцький. Список супроводжувався рапортом iз Харкова від місцевого жандармського генерал-майора шефу жандармів і головному начальнику III відділення від 5 травня 1863 р., де йшлося про утворення в Харкові «малоросійського гуртка», учасники якого носили «малоросійський костюм», розмовляли «на наріччі», тобто українською мовою, поширювали в народі грамотність, збирали гроші для М. І. Костомарова ${ }^{22}$.

Як бачимо, вже на початку 1860-х рр. ходити в українському національному вбранні чи розмовляти українською мовою в уяві російських імперських чиновників було «небезпечним» для основ царського режиму. Загалом в 60-90-х рр. XIX ст. можна нарахувати не менше десятка офіційних імперських заборон та обмежень стосовно української мови, освіти та культури. Звичайно, розвитку українознавства і української національної свідомості не сприяли такі відомі акції царизму, як заборона недільних шкіл (1862), Валуєвський циркуляр (1863), Емський указ (1876) тощо. Але українознавство не припиняло свого поступу всупереч зазначеному.

Кумиром харківських громадівців був тоді ще молодий український мовознавець i фольклорист О. О. Потебня, який свого часу формувався під впливом А. Л. Метлинського, належав до його послідовних однодумців. На початку своєї діяльності він брав участь у засіданнях громади, з великою цікавістю вів мову про історичне минуле, про українську пісню та поезію, про пам'ятки української народної словесності. Харківська молодь захоплено слухала вченого. О. О. Потебня ініціював мандрівки з метою «придивитись і прислухатись до народного життя й мови» ${ }^{23}$.

О. О. Потебня належав до ерудитів у багатьох галузях мовознавства. У 1861 р. вчений захистив магістерську дисертацію «Про деякі символи в слов'янській народній поезії», а у 1874 р. докторську - «Із записок з руської граматики». У 1863-1874 рр. О. О. Потебня плідно працював доцентом, а в 1875-1891 рр. ординарним професором, завідувачем кафедри російської словесності Харківського університету. В українознавчій спадщині вченого найбільше представлені мова й етнографія. Це, зокрема, «Заметки о малорусском наречии» (1871), «Объяснения малорусских и сродных народных песен» у двох томах (1883, $1887)$, «Разбор сочинения П. Житецкого «Очерк звуковой истории малорусского наречия» (К., 1876) (1879), рецензія на працю «Народные песни Галицкой и Угорской Руси, собранные Я. Ф. Головацким» (М., 1878) (1880) та ін. А праця вченого «Мысль и язык» витримала в дореволюційний період три видання $(1862,1892,1913)$.

Досконало знаючи українську мову, О. О. Потебня переклав на неї віршами частину «Одисеї» Гомера, видав поезії П. П. Гулака-Артемовського, оповідання Г. Ф. КвіткиОснов'яненка. Об'єктом зацікавлень ученого була й українська народна пісенна спадщина. Так, у 1863 р. коштом О. С. Балліної вийшла у світ збірка українських народних пісень, записаних О. О. Потебнею.

Учений-україніст виступав за якнайширший розвиток усіх народностей і їх мов, включаючи український народ. У творчому доробку знаного дослідника

українознавчі й слов'янознавчі наукові зацікавленості тісно переплітались. У праці «Мова і народність» (1895) О. О. Потебня науково обгрунтував рівноправність мов та народів.

Відомий вчений-філолог користувався великою повагою в інтелектуальному колі харків'ян. Цілком закономірно, що впродовж 12-ти років з 1877 по 1890 рр. О. О. Потебня 
очолював Історико-філологічне товариство при Харківському університеті. Д. І. Багалій цілком справедливо називав О. О. Потебню «великим лінгвістом», «найславнішим 3 професорів Харківського університету». Та й дійсно науковий доробок професора у галузях філології та етнографії здобув справжнє визнання й високі нагороди. Наукова і громадська діяльність О. О. Потебні мала велике значення не тільки для утвердження різних галузей українознавства, а й закладала підгрунтя для формування української національної свідомості в його учнів та послідовників ${ }^{24}$.

До лав харківських громадівців належав студент університету В. С. Гнилосиров (Гнилосир), який ще під час навчання разом із В. С. Мовою, О. О. Потебнею та іншими поширював серед народу українські книжки. У $1860-1863$ рр. він під час канікул здійснював «ходіння в народ», розповсюджував книжки і портрети Т. Г. Шевченка. Так, улітку 1861 p. В. С. Гнилосиров разом із братами А. Л. та І. Л. Шимановими подорожував по селах Харківщини та Волині, а наступного літа з О. О. Потебнею та Чириковим - по Харківщині й Полтавщині. Відомо, що в 1862 р. цей харківський студент-громадівець продав 118 примірників українських книжок. Він мав зв'язок з ідейним лідером Київської Старої громади В. Б. Антоновичем, писав вірші про Т. Г. Шевченка, друкувався в журналі «Основа», а згодом у «Зорі» та «Киевской старине». Його перу належать поема «Закохана» (1893), казка «Царівна-русалка» (1895) та збірник «Оновлення» $(1897)^{25}$

Ще одним учасником Харківської української громади був студент і випускник Харківського університету 1867 р. В. С. Мова. Свою діяльність як український поет він розпочав у 1861 р., дописуючи в журнал «Основа». У його спадщині - ліричні вірші, поеми, прозові та драматичні твори, неповний український переклад поеми «Слово о полку Ігоревім» ${ }^{26}$.

До кола Харківської української громади належав А. Л. Шиманов, який в 1860 p. закінчив Харківський університет, а після цього відвідував педагогічні курси, давав приватні уроки та займався у 2-й недільній школі, якою керував професор В. І. Лапшин. Як український народолюбець, він подорожував Полтавщиною, Київщиною, Волинню, здійснюючи «добросовісне етнографічне вивчення краю». Результати своєї мандрівки він виклав у часопису «Основа». А. Л. Шиманов отримував вісті від однодумців із Волині, Поділля, з Київщини і Полтавщини, мав контакти з діячами Полтавської та Київської Старої громад. Цікаво, що російські жандарми перехопили листування, де йшлося, що «Антонович дійсно тлумачить про те ж, про що говорив Шиманов». У 1862 р. його національно-культурницька діяльність була кваліфікована царською владою як «поширення малоросійської пропаганди», і кандидат Харківського університету А. Л. Шиманов був заарештований ${ }^{27}$.

Помітний внесок у галузі фольклористики, етнографії та літературознавства зробив М. Ф. Сумцов - випускник історико-філологічного факультету Харківського університету (1875), який згодом захистив докторську дисертацію «Хліб в обрядах і піснях» (1885), став професором (1888), завідувачем університетського етнографічного музею (1905), головою Харківського історико-філологічного товариства (1897-1919). Взагалі у творчому доробку видатного вченого близько 800 наукових праць 3 української фольклористики та етнографії, а всього - 1544 бібліографічні позиції. Важливе значення для подальшого розвитку цих галузей знань українознавства мали такі праці, як «Научное изучение колядок и щедрівок» (1886), «Коломыйки» (1886), «Культурные переживания» (1889-1890), «Писанки» (1891), «Современная малорусская этнография» в двох томах $(1893,1897)$, «Из украинской старины» (1902), «Очерки народного быта» (1902), «Изучение кобзарства» (1905), «Діячі українського фольклору» (1910), «Слобідсько-українські історичні пісні» (1914), історико-етнографічна розвідка «Слобожане» (1918) та ін. Вчений створив малу енциклопедію етнографічних понять і реалій для фундаментальної енциклопедії Брокгауза й Ефрона ${ }^{28}$.

Значну увагу М. Ф. Сумцов приділяв розвитку місцевої етнографії, фольклористики, краєзнавства. Впродовж багатьох років авторитетний вчений підтримував слобожанських аматорів, зокрема фольклориста та етнографа П. В. Іванова, поета та збирача творів усної народної творчості I. І. Манжуру. Разом із Д. І. Багалієм, приватним адвокатом і співробітником «Киевской старины» А. Л. Шимановим, Д. І. Яворницьким він входив до складу гуртка Я. І. Щоголєва (Щоголіва). Очільник цього осередку, який свого часу перебував під впливом харківських романтиків, у другій половині XIX ст. продовжував працювати у 
жанрі українські поезії. 3-під його пера вийшли у світ такі поетичні збірки, як «Ворскло» (1883), «Слобожанщина» $(1898)^{29}$.

М. Ф. Сумцов щиро вболівав за поліпшення освітнього рівня і самосвідомості українства. Ще в дореволюційний період вчений підготував і видав у світ такі промовисті праці, як «Новейшая поэзия как образовательное средство для крестьян» (1883), «Старі зразки української народної словесності» (1910), «Малюнки з життя українського народного слова» (1910). Він очолив спеціальну комісію, яка підготувала для Вченої ради університету рішення про скасування існуючих заборон на видання літератури українською мовою (1905), ініціював викладання у Харківському університеті україномовного факультативного курсу «Історія малоросійської народної словесності» (1907) та започаткування Харківською міською думою Шевченківської премії для підтримки кращих студентських наукових робіт з історії України, літератури та етнографії (1911) тощо.

Окрім О. О. Потебні та М. Ф. Сумцова третім українолюбцем й українознавцем на історико-філологічному факультеті Харківського університету був Д. І. Багалій - учень В. Б. Антоновича. Розпочавши свою науково-педагогічну діяльність у 1883 р., у віці 26-ти років, доцент Д. І. Багалій відразу привернув увагу тих студентів, котрі належали до свідомих українців. Вони оцінили український світогляд свого лектора, що спирався на федеративні ідеї. Навколо нього швидко склався гурток, що цікавився питаннями українознавства. Під керівництвом Д. І. Багалія було розпочато роботу над складанням бібліографічного покажчика літератури про українську історію. Та й літографований лекційний курс історика «Лекції по истории Юго-Западной Руси» (1890) подавав в основних рисах всю історію України з половини XIV до половини XVIII ст., мав новаторський характер і звертав головну увагу на соціально-економічні та культурні явища українського історичного процесу ${ }^{30}$.

У 1887 р. Д. І. Багалій захистив докторську дисертацію «Очерки из истории колонизации и быта степной окраины Московского государства» в Московському університеті та був призначений екстраординарним професором Харківського університету. 3-під пера вченого вийшли фундаментальні праці: «Очерки из истории колонизации и быта степной окраины Московского государства» (1887), «Украинская Старина (очерки, заметки, материалы из стародавнего Харьковского быта и культуры» (1896), «Опыт истории Харьковского университета (по неизданным материалам)» у двох томах (1899, 1904), «История города Харькова за 250 лет его существования» у двох томах (1905, 1912, у співавторстві з Д. П. Міллером), «История Слободской Украины» (Т. 2, 1913), «Історія Слобідської України» (1918) та ін., у яких застосував методологію модернізованого класичного позитивізму.

Загалом українознавчі зацікавлення вченого вирізнялися свою широтою. У творчому доробку Д. І. Багалія праці з археології України, архівної справи в Україні, українського джерелознавства й історіографії, історії стародавньої історії України-Руси, історії Слобідської України, з історії Запорожжя і Південної України, з історії Лівобережної України, 3 історії громадської думки й революційних рухів в Україні, з історії української культури, освіти й письменства, краєзнавства. Ця українознавча спадщина представляла не тільки науковий інтерес, а мала вплив на формування української національної свідомості у його учнів та читачів ${ }^{31}$.

Культурницько-просвітницька діяльність Д. І. Багалія дореволюційного періоду сприймалася консервативними й реакційними силами як українофільська. Її відмітними особливостями була подвійна лояльність, яка виражалася, з одного боку, у виконанні вченим настанов російської імперської влади в якості посадової особи, особливо періоду ректорства 1906-1911 рр., та як члена Державної Ради 1906-1907, 1911-1914 pр., а з іншого, - у прагненнях засобами українознавства, хоча й одягнутого в шати історичного краєзнавства чи обласництва, розкрити ще не знані сторінки української історії; у публічних ініціативах (разом із М. Ф. Сумцовим, М. Є. Халанським та іншими вченими) виступити на захист прав української мови (1905) та відкрити у Харківському університеті кафедри української мови та історії (1906-1907), в започаткуванні україномовного факультативного курсу «Історія малоросійської народної словесності» (1907) тощо. Така світоглядна двоїстість простежувалась навіть удома, де Д. І. Багалій перейшов у сімейному спілкуванні на російську мову, хоча водночас широко використовував український фольклор під час 
читання вголос, виконання українських пісень і театральних вистав. Втім, українознавча традиція, розвинута вченим, знайшла своїх послідовників ${ }^{32}$.

Одним із однодумців Д. І. Багалія був М. С. Халанський, випускник Харківського університету 1881 р., який згодом став професором (1892), членом-кореспондентом Петербурзької АН (1909). Предметом наукових зацікавлень ученого була українська фольклористика та діалектологія. У 1881 р. водночас із М. Є. Халанським закінчив Харківський університет Д. І. Яворницький. 31883 р. разом зі своїми вчителями О. О. Потебнею та М. Ф. Сумцовим, а також з Д. І. Багалієм, П. С. Єфименком, М. Є. Халанським та іншими вченими він брав участь у діяльності місцевого Історико-філологічного товариства при Харківському університеті.

У харківський період своєї діяльності (1877-1885) Д. І. Яворницький розпочав всебічне вивчення Запорожжя, а з часом утвердився як справжній знавець козаччини, вивчаючи історичні, археологічні, архівні, фольклорно-етнографічні, мовно-літературні скарби Запорозького краю. Проте розпочате дослідження запорозької старовини не схвалили, запропонувавши молодому історику вивчати минуле Фінляндії, а після його відмови визнали незручним подальше перебування в Харківському університеті як «явного українофіла». Проте епістолярна спадщина Д. І. Яворницького свідчить, що деякі його харківські учні, наприклад В. Каплуновський, вже в середині 1880-х рр. сприймали свого молодого вчителя як «українця». Та і вся подальша діяльність Дмитра Івановича - яскравий приклад вибору на користь української національної свідомості й ідентичності, самовідданого служіння українській національній науці та освіті. Прикметно, що підозри в «українофільстві» та «сепаратизмі» з боку царських чиновників тяжіли на українським вченим від 1880-х рр. і до Першої світової війни.

До славних випускників Харківського університету пореформеного періоду, котрі залишили помітний слід в історії української культури та українського національного руху, належали такі знакові постаті, як М. Ф. Комаров, М. В. Лисенко, М. П. Старицький та ін. До плеяди харківських професорів початку XX ст., який зробили свій внесок у поступ українознавчих студій, що поєднувалися з фаховим інтересом до візантології та славістики, варто віднести мовознавця-славіста й палеографа С. М. Кульбакіна, історика мистецтв та археолога Є. К. Рєдіна, історика архітектури, малярства, мистецтвознавця та музеєзнавця Ф. Шміта та ін. ${ }^{33}$.

Звичайно, не можна перебільшувати роль українознавства у процесі становлення української національної свідомості й ідентичності. Значна частина харківської професури зовсім не сприймала українського світогляду. Так, коли Д. І. Яворницький попросив М. Ф. Сумцова посприяти в отриманні докторства в Харківському університеті, то той у листі-відповіді 7 березня 1918 р. відповів «щирому українцю», що харківська професура до українського ставиться «вороже занадто і українською мовою нехтує», радив перетерпіти якийсь час і залишатися на старому місці в Катеринославі ${ }^{34}$.

Висновки. Як бачимо, вже наприкінці 1820-х - упродовж 1840-х рр. ряд професорів, викладачів та студентів Харківського університету прилучилися до україністики, працюючи в галузях історії, фольклористики, етнографії, літератури, видавничої справи, вивчаючи поетичну та пісенну спадщину українського народу. Цей процес відбувався під романтичними та слов'янофільськими впливами, українолюбними й народолюбними зацікавленостями, інколи свою роль відігравали морально-етичні та естетичні чинники. Національні мотиви тільки-но формувалися і далеко не завжди були присутні в кристалізованому вигляді. Втім, ці культурницькі зусилля харків'ян у справі збирання, вивчення i збагачення спадщини українського народу готували інтелектуальний грунт для національного самоусвідомлення, світоглядним містком до якого була українська народна ідея.

Актуалізовані ідеї народолюбства й українолюбства набули більшої зрілості на культурно-політичному етапі національного поступу і значно активніше виявлялися впродовж 1860-1880-х pр., коли вчені перейшли на позиції методології позитивізму. У свою чергу це сприяло поступу українознавчих студій і впровадженню відповідної проблематики в соціальну практику.

На рубежі XIX-XX ст., коли поступово утверджувалася політична стадія українського націотворення, представники патріотично налаштованої частини професорсько-викладацького складу та студентства Харківського університету продовжили розвиток різних 
галузей українознавства, актуалізуючи його проблематику у непростих суспільно-політичних умовах російського імперського режиму, які виявлялися в політичних переслідуваннях «українофілів», цензурних утисках, мовно-культурних обмеженнях. Ця інтелектуальна діяльність мала важливе значення у справі відстоюванні права українського народу на власну мову, освіту, науку та культуру, сприяла поступу української національної свідомості та ідентичності серед «щирих українців». На жаль, лави таких були ще нечисленними. Українознавчі студії харківських вчених часто здійснювались водночас з їхніми науковими дослідженнями в різних галузях славістики. Це невипадково, бо становлення української модерної нації було складовою процесу творення інших слов’янських націй.

1 Харківський університет і українська культура (210-річчя від часу заснування ХНУ імені В. Н. Каразіна): моногр. / [кол. авт.]; передм. В. С. Бакірова; за ред. Ю. М. Безхутрого. Х., 2015. C. 7-32.

${ }^{2}$ Мандебура О. Микола Сумцов і проблеми соціокультурної ідентичності. К., 2011. С. 57-111.

${ }^{3}$ Франчук В. Ю. Олександр Опанасович Потебня. К., 2012. С. 72-111, 174-240, 322-326.

${ }^{4}$ Юрчук В. I. П'ятдесят літ на сторожі української науки та культури: моногр. К., 2012. С. $24-111$.

${ }^{5}$ Ефименко А. Я. История украинского народа. К., 1990. С. 386, 481.

${ }^{6}$ Багалей Д. И., Миллер Д. П. История города Харькова за 250 лет его существования (16551905). Историческая монографія: в 2 т. Т. II. Репринт. изд. Х., 1993. С. 804-805.

${ }^{7}$ Ректори Харківського університету (1805-2014): біобібліограф. довідник / уклад. В. Д. Прокопова, Р. А. Ставинська, М. Г. Швалб та ін.; ред. кол.: В. С. Бакіров (голов. ред.) та ін. Х., 2015. С. 44; Вихованці Харківського університету. Біобібліогр. довідник / авт.-уклад.: Б. П. Зайцев, В. І. Кадєєв, С. М. Куделко та ін. Х., 2004. С. 59.

${ }^{8}$ Багалей Д. И., Миллер Д. П. История города Харькова за 250 лет его существования (16551905). С. 807-809; Грушевский М. С. Очерк истории украинского народа. К., 1990. С. 315.

${ }_{9}$ Потульницький В. А. Україна і всесвітня історія: Історіософія світової та української історії XVII-XX століть. К., 2002. С. 265-268; Ректори Харківського університету (1805-2014)... С. 26.

${ }^{10}$ Грушевский М. С. Очерк истории украинского народа. К., 1990. С. 315; Грушевський М. Ілюстрована історія України. Репринт. відтвор. вид. 1913 року. К., 1992. С. 490; Вихованці Харківського університету. Біобібліогр. довідник / авт.-уклад.: Б. П. Зайцев, В. І. Кадєєв, С. М. Куделко та ін. Х., 2004. С. 183-184; Ефименко А. Я. История украинского народа. С. 481; Істория української культури / за заг. ред. Івана Крип’якевича. К., 1999. С. 294; Харківський університет і українська культура... C. $11-13$.

11 Ефименко А. Я. История украинского народа. С. 385; Чижевський Д. Історія української літератури (від початків до доби реалізму). Тернопіль, 1994. С. 371.

${ }^{12}$ Багалей Д. И. История города Харькова за 250 лет его существования (1655-1905). Историческая монографія: в 2 т. Т. II. С. 812; Вихованці Харківського університету. Біобібліогр. довідник / авт.-уклад.: Б. П. Зайцев, В. І. Кадєєв, С. М. Куделко та ін. Х., 2004. С. 130; Ефименко А. Я. История украинского народа. С. 386; Сумиов М. Ф. А. Л. Метлинський // Дослідження з етнографії та історії культури Слобідської України. Х., 2008. С. 351.

${ }_{13}$ Костомаров Н. И. Автобиография. Бунт Стеньки Разина. К., 1992. С. 101-102, 104, 109-110, 111-113; Багалей Д. И., Миллер Д. П. История города Харькова за 250 лет его существования (16551905). Историческая монографія: в 2 т. Т. II. Х., 1993. С. 811; Інститут літератури ім. Т. Г. Шевченка НАН України. Відділ рукописних фондів та текстології. Ф. 77. Спр. 125. Арк. 34зв.

${ }^{14}$ Костомаров Н. И. Автобиография. С. 114. C. 274 .

15 Дорошенко Д. Нарис історії України: у 2 т. Т. II (від половини XVII століття). К., 1992.

${ }^{16}$ Вихованці Харківського університету. Біобібліогр. довідник. С. 32-33; Ефименко А. Я. История украинского народа. С. 386.

${ }_{17}^{17}$ Вихованці Харківського університету. Біобібліогр. довідник. С. 101

${ }^{18}$ Там само. С. 151.

${ }^{19}$ Багалей Д. И., Миллер Д. П. История города Харькова за 250 лет его существования (16551905). Историческая монографія: в 2 т. Т. II. С. 815; Вихованці Харківського університету. Біобібліогр. довідник. С. 225.

${ }^{20}$ Алчевская Х. Д. Передуманное и пережитое. Дневники, письма, воспоминания. М., 1912. С. 452 ; Супронюк О. Харківська громада наприкінці 1862 р. // Київська старовина. 1998. № 2. С. $188-189$. 183в.

${ }^{21}$ Центральний державний історичний архів України у м. Києві. Ф. 442. Оп. 811. Спр. 91. Арк.

${ }^{22}$ Государственный архив Российской Федерации. Ф. 109. 1 эксп., 1862 г. Д. 230. Ч. 128. Л. 118, 118об., 121. 
${ }^{23}$ Алчевская Х. Д. Передуманное и пережитое. Дневники, письма, воспоминания. М., 1912. С. 453; Багалій Д. I. Автобіографія. П’ятдесят літ на сторожі української культури. В.: Вибрані праці: у 6 т. Т. 1: Автобіографія. Ювілейні матеріали. Бібліографія / упорядк., вступ. ст., комент. В. В. Кравченка; редкол.: В. В. Кравченко (голов. ред.) та ін. Х., 1999. С. 116; Житецький I. О. О. Потебня і харківська громада в 1861-1863 рр. (із щоденника та листування В. С. Гнилосирова) // За сто літ. 1927. Кн. 1. С. 74; Сумщов М. Ф. Пятидесятилетіе сборника А. Л. Метлинськаго «Народныя южнорусскыя песни». // Сумцов М. Ф. Дослідження з етнографії та історії культури Слобідської України. Х., 2008. C. 366.

${ }^{24}$ Багалій Д. І. Історія Слобідської України. Х., 1993. С. 227; Вихованці Харківського університету. Біобібліогр. довідник. С. 159; Олександр Опанасович Потебня. Біобібліографічний покажчик. Х., 2005. С. 9-10; Франчук В. Ю. Олександр Опанасович Потебня. К., 2012. С. 319, 322-324; Харківський університет і українська культура (до 210-річчя від часу заснування ХНУ імені В. Н. Каразіна). С. 20; Чикаленко С. Спогади (1861-1907). К., 2003. С. 101.

${ }^{25}$ Вихованці Харківського університету. Біобібліогр. Довідник. С. 49-50; Гавриши А. [Гнилосиров B.]. Пять день 3 життя Х-го студента (Вічній памяті Т. Гр. Шевченка) // Основа. 1862. № 9. С. 64, 73; Житецький I. О. О. Потебня і харківська громада в 1861-63 pр. (із щоденника та листування В. С. Гнилосирова) // За сто літ. 1927. Кн. 1. С. 74; Інститут рукопису НБУ ім. В. І. Вернадського НАН України. Відділ рукописів. Ф. ІІІ. Спр. 4101.

${ }^{26}$ Вихованці Харківського університету. Біобібліогр. Довідник. С. 137.

${ }^{27}$ Гніп М. Громадський рух 1860 рр. на Україні. Полтавська громада. Х., 1930. С. 96, 97, 128, 129; Государственный архив Российской Федерации. Ф. 109. Оп. 223. Д. 27. Л. 17; Там же. Ф. 109. 1 эксп., 1862 г. Д. 230. Ч. 128. Л. Б. Л. 7об.-8, 44об.-45.

${ }_{28}^{28}$ Вихованці Харківського університету. Біобібліогр. Довідник. С. 191; Красиков Михайло. Вдячний син Слобожанщини. Микола Сумцов - дослідник і громадський діяч краю // Сумцов М. Ф. Дослідження з етнографії та історії культури Слобідської України. Вибр. праці / упорядк., підгот. тексту, передмова, післямова та примітки М. М. Красикова. Х., 2008. С. 4, 24, 25; Мандебура О. Микола Сумцов і проблеми соціокультурної ідентичності. С. 265-268; Сумиов М. Ф. Життєпис Я. Щоголіва // Сумцов М. Ф. Дослідження з етнографії та історії культури Слобідської України. С. 398; Харківський університет і українська культура (до 210-річчя від часу заснування ХНУ імені В. Н. Каразіна). С. 21

${ }^{29}$ Красиков М. Вдячний син Слобожанщини. С. 25-27; Сумщов М. Ф. Життєпис Я. Щоголіва. С. 398; Харківський університет і українська культура (до 210-річчя від часу заснування ХНУ імені В. Н. Каразіна). С. 23 .

${ }^{30}$ Багалій Д. І. Автобіографія. П’ятдесят літ на сторожі української культури. В.: Вибрані праці: у 6 т. Т. 1: Автобіографія. Ювілейні матеріали. Бібліографія / упорядк., вступ. ст., комент. В. В. Кравченка; редкол.: В. В. Кравченко (голов. ред.) та ін. Х., 1999. С. 116, 132; Харківський університет і українська культура (до 210-річчя від часу заснування ХНУ імені В. Н. Каразіна). С. 28, 30; Юрчук B. I. П'ятдесят літ на сторожі української науки та культури. С. 193.

${ }^{31}$ Богдашина О. М. Слобідський літописець історії України Д. І. Багалій // Укр. іст. журн. 2008. № 1. С. 94-95; Юрчук В. I. П’ятдесят літ на сторожі української науки та культури. К., 2012. С. 47-49, $188-210$

${ }^{32}$ Богдашина О. М. Слобідський літописець історії України Д. І. Багалій. С. 92-93, 94, 97-98.

${ }_{33}$ Світленко C. Дмитро Яворницький: вчений і педагог в українському інтелектуальному співтоваристві: моногр. 2-ге вид. Д., 2017. С. 29-30, 32-33, 53, 59-60, 280; Харківський університет і українська культура (до 210-річчя від часу заснування ХНУ імені В. Н. Каразіна). С. 22-26.

${ }^{34}$ Світленко С. Дмитро Яворницький: вчений і педагог в українському інтелектуальному співтоваристві: моногр. 2-ге вид. Дніпро, 2017. С. 207. 